\title{
Peptococcus niger (Hall) Kluyver and van Niel 1936: Emendation of Description and Designation of Neotype Strain
}

\author{
TRACY D. WILKINS, W. E. C. MOORE, S. E. H. WEST, AND L. V. HOLDEMAN \\ Anaerobe Laboratory, Virginia Polytechnic Institute and State University, Blacksburg, Virginia 24061
}

ATCC strain no. 27731 (VPI 7953) is described and designated as the neotype strain of Peptococcus niger (Hall) Kluyver and van Niel 1936. This strain conforms in all respects to the original description of the single isolate of Micrococcus niger Hall 1936. Additional strains from eight people are also described.

In 1930, I. C. Hall isolated and described an anaerobic gram-positive coccus that formed black-pigmented colonies (2) and named it Micrococcus niger. Later, when Kluyver and van Niel created the genus Peptococcus (3), they designated this organism the type species of the genus. Hall's description was based on a single strain isolated from the urine of an aged woman (2). The original strain apparently is no longer extant. We have not found it in any type culture collection nor in Hall's personal collection of anaerobic bacteria, which was given to the Virginia Polytechnic Institute and State University (VPI \& SU) Anaerobe Laboratory. However, we did find Hall's original records and worksheets, which have been of considerable help in determining the characteristics of the original strain of Peptococcus niger (Hall) Kluyver and van Niel.

$P$. niger (Hall) Kluyver and van Niel was originally described by Hall (2) as an obligately anaerobic coccus about $0.6 \mu \mathrm{m}$ in diameter forming irregular masses resembling staphylococci. This organism formed colonies $(0.5 \mathrm{~mm}$ in diameter) that were dark black, irregularly globular, smooth, and dense in $1 \%$ meat infusion agar with $2 \%$ peptone. Upon exposure to air these colonies faded to a dull gray color. On blood agar the colonies in 5 days "arose like tiny black pearls, round, smooth and glistening." The organism was nonhemolytic, did not liquefy gelatin or serum, did not digest milk, and did not ferment carbohydrates. This organism did produce $\mathrm{H}_{2} \mathrm{~S}$.

During bacteriological monitoring by technologists of Brown, Root and Northrup, Houston, Tex., of the flora of three astronauts participating in a mock Skylab flight, cocci that formed black colonies on blood agar plates were repeatedly isolated from swabs of the navel of one astronaut. This organism was not isolated from swabs from any other site on his body or from the other two astronauts. This organism
(VPI strain no. 7726) was submitted to the Anaerobe Laboratory of VPI \& SU for identification, and we determined that it had characteristics of $P$. niger. Because of the taxonomic importance of this coccus as the type species of the genus Peptococcus, we tried to isolate additional strains. This paper designates ATCC strain no. 27731 (VPI strain no. 7953) as the neotype strain and describes additional strains from eight different people.

\section{MATERIALS AND METHODS}

Cultures. The strains examined and their sorrces are listed in Table 1.

Media. Blood agar plates were made with brain heart infusion agar (Difco) with $4 \%$ laked sheep blood and $0.5 \%$ yeast extract added.

Loeffler's blood serum and meat infusion-peptone agar were made according to the procedure given by Hall (1). For Loeffler's blood serum, 1 part of neutral beef broth containing $1 \%$ glucose, $1 \%$ peptone (Difco), and $0.5 \% \mathrm{NaCl}$ was mixed with 3 parts of beef serum. Slants were made and sterilized by inspissation.

Meat infusion-peptone agar was prepared by making an overnight infusion from $500 \mathrm{~g}$ of ground beef and 1 liter of distilled water. The infusion was boiled vigorously for $10 \mathrm{~min}$ and strained through cheesecloth, and the meat was discarded. Peptone $(20 \mathrm{~g})$ and $\mathrm{NaCl}(5 \mathrm{~g})$ were added; the mixture was boiled to dissolve the ingredients and then cooled. The $\mathrm{pH}$ was adjusted to 7.0 with $\mathrm{NaOH}$, and $12 \mathrm{ml}$ was pipetted into screw-capped tubes containing $0.25 \mathrm{~g}$ of agar and autoclaved at $15 \mathrm{lb} / \mathrm{in}^{2}$ for $15 \mathrm{~min}$.

Chopped-meat agar was prepared as described previously for chopped-meat broth (2a) except that agar to give a final $2 \%$ concentration was added to each tube before autoclaving and no meat particles were included in the final medium.

Carbohydrates tested. The carbohydrates tested were: adonitol, amygdalin, arabinose, cellobiose, dextrin, dulcitol, erythritol, esculin, fructose, galactose, lactose, maltose, mannitol, mannose, melezitose, melibiose, raffinose, rhamnose, ribose, salicin, sorbitol, sorbose, starch, sucrose, trehalose, and xylose.

Anaerobiosis. Blood agar plates were placed in anaerobe jars containing palladium catalyst, evacu- 
TABLE 1. Source of Peptococcus niger strains examined

\begin{tabular}{cc}
\hline VPI no. & \multicolumn{1}{c}{ Source } \\
\hline $3206 \mathrm{~F}$ & $\begin{array}{c}\text { Culture of drainage from rectal abscess; } \\
\text { received from A. Balows, Lexington } \\
\text { Clinic, Lexington, Ky. }\end{array}$ \\
& $\begin{array}{c}\text { Culture from a pilonidal cyst; received } \\
\text { from Corning Hospital, }\end{array}$ \\
& Corning, N.Y. \\
7726 & Culture isolated from a navel swab; \\
& received from Brown, Root and \\
7953 & Northrup, Houston, Tex. \\
& Navel swab, W.M., Oct. 1972 \\
8045 & (ATCC 27731) \\
8046 & Navel swab, T.S., Nov. 1972 \\
8047 & Navel swab, R.G., Nov. 1972 \\
8878 & Navel swab, G.R., Nov. 1972 \\
8893 & Vaginal area swab, T.S., Aug. 1973 \\
& Navel swab, J.H., Aug. 1973 \\
\hline
\end{tabular}

ated, and filled with $90 \% \mathrm{H}_{2}$ and $10 \% \mathrm{CO}_{2}$. Prereduced tube media were prepared as previously described (6). To reproduce Hall's (2) methods, we used alkaline pyrogallol (4) for maintaining anaerobiosis of blood agar slants and of the Loeffler coagulated blood serum.

Determination of $\% \mathbf{G}+\mathbf{C}$. The percent guanine plus cytosine $(\% \mathrm{G}+\mathrm{C})$ of the deoxyribonucleic acid preparations was determined by their thermal melting point $\left(\mathrm{T}_{m}\right)(5)$, using an automatic spectrophotometer (Gilford Instrument Laboratories). Escherichia coli $\mathrm{B}$ deoxyribonucleic acid was included in each spectrophotometer run as a standard.

Isolation from skin. Dry cotton swabs were vigorously rubbed on the skin surface to be tested and then rubbed onto a small area of a blood agar plate. This material was then streaked to obtain isolated colonies. The plates were incubated for 5 days in anaerobe jars. All black colonies were picked into chopped-meat broth (6). Cultures yielding gram-positive cocci were streaked again to insure purity.

Characterization. Pure cultures were characterized by using media and methods previously described (2a).

\section{RESULTS AND DISCUSSION}

Isolation from human navels. The navels of approximately 150 people were tested for the presence of cocci that formed black pigment on blood agar plates. We isolated such organisms from the navels of five people. Two persons (one male, one female) were available for repeated culturing. We obtained repeated navel isolates from both of them at each of three samplings over a 12 -month period. Swabs also were obtained from skin surfaces at 40 different locations scattered completely over the body of these two volunteers. Samples from W.M. were negative in all areas except the navel; one swab from the vaginal area of T.S. was positive in addition to the navel swab. These data indicate that black-pigmented cocci arr present in the normal flora of the navels or a minority of the North American population and that these organisms are not distributed over the entire skin of these individuals. All navel strains appeared similar in cultural reactions and also appeared similar to two clinical isolates (Table 1) in the culture collection of the VPI Anaerobe Laboratory.

Characteristics of strains. The strains were obligately anaerobic, nonmotile, gram-positive cocci. The cells from 24-h peptone-yeast extract-glucose cultures were 0.3 to $1.3 \mu \mathrm{m}$ in diameter; the average diameter was $0.7 \mu \mathrm{m}$. The cells occurred singly and in pairs, tetrads, and irregular masses. No chains were observed.

On initial isolation, the colonies on blood agar plates were black, minute to $0.5 \mathrm{~mm}$, circular with entire margins, convex, shiny, smooth, and nonhemolytic. After several laboratory transfers or freeze drying, black colonies on blood agar plates were no longer observed. These nonpigmented colonies were like the pigmented colonies except that they were white and translucent. However, both fresh isolates and strains that would no longer form black colonies on blood agar plates did form pigmented colonies repeatedly in meat infusion-peptone agar deeps and in chopped-meat agar roll tubes. These colonies in the agar were minute to $0.5 \mathrm{~mm}$, black, and lenticular. As described by Hall, if the black colonies were exposed to air, they turned light gray. Growth in peptone-yeast extract broth was nonturbid with a slight smooth white or grayish-white sediment.

Surface colonies on anaerobic slants of chopped-meat agar were $1 \mathrm{~mm}$, circular, entire, convex, opaque, and white to light gray. There was no growth on either Loeffler's coagulated blood serum or blood agar slants, using alkaline pyrogallol to establish anaerobiosis.

The following reactions were uniformly negative: digestion of gelatin, meat, milk, and esculin; production of indole and acetoin; production of lecithinase and lipase; reduction of nitrate; and utilization of lactate, starch, and hippurate. All strains produced $\mathrm{H}_{2} \mathrm{~S}, \mathrm{NH}_{3}$, and $\mathrm{H}_{2}$ and weakly decomposed $\mathrm{H}_{2} \mathrm{O}_{2}$. No carbohydrate tested was fermented, but pyruvate was utilized. Gas was produced in peptone-yeast extract-glucose agar deeps. Peptone-yeast extract-pyruvate cultures were turbid with a smooth gray sediment. The fermentation products (average milliequivalents per $100 \mathrm{ml}$ of replicate cultures of all eight strains) of $P$. niger in peptone-yeast extract-pyruvate medium were: acetic (3.5), isobutyric (0.3), butyric (1.2), 
isovaleric (0.6), and caproic (0.4) acids. Occasionally, trace amounts of propionic, valeric, lactic, and succinic acids were produced.

The $\% \mathrm{G}+\mathrm{C}$ of the neotype strain is 50 . The neotype strain is ATCC 27731 (VPI 7953 isolated from the navel of W.M.).

Differentiation from other anaerobic cocci. Production of caproate and no fermentation of carbohydrates differentiate $P$. niger from $P e p$ tostreptococcus anaerobius, the anaerobic gram-positive coccus that it most closely resembles in cultural characteristics. Strains of $P$. anaerobius do not form black colonies on blood agar plates, even though they may form black colonies in glucose agar deeps. $P$. niger is the only anaerobic coccus that we have found to form black colonies in chopped-meat agar deeps as originally described by Hall (2).

\section{ACKNOWLEDGMENTS}

We are indebted to John Johnson for performance of the $\% \mathrm{G}+\mathrm{C}$ of the deoxyribonucleic acid and to the individuals that sent us cultures of black-pigmented cocci. Photomicrographs were taken by Maeve Crowgey. This work was supported by Public Health Service grant no. GM 14604 from the National Institute of General Medical Sciences.

\section{REPRINT REQUESTS}

Address reprint requests to: Dr. Tracy D. Wilkins, Division of Basic Sciences, VPI \& SU Anaerobic Laboratory, P. O. Box 49. Blacksburg, Va. 24060.

\section{LITERATURE CITED}

1. Hall, I. C. 1924. Laboratory manual in general bacteriology.

2. Hall, I. C. 1930. Micrococcus niger, a new pigment forming anaerobic coccus recovered from urine in a case of general arteriosclerosis. J. Bacteriol, 20:407-415.

2a. Holdeman, L. V., and W. E. C. Moore (ed.). 1973. Anaerobe laboratory manual, 2nd ed. VPI \& SU Anaerobe Laboratory, Blacksburg. Va.

3. Kluyver, A. J., and C. B. van Niel. 1936. Prospects for a natural system of classification of bacteria. Zentralbl. Bakteriol. Parasitenk. Infektionskr. Abt. 2 94:369-403.

4. Committee on Bacteriological Technic of the Society of American Bacteriologists (ed.). 1950. Manual of methods for pure culture study of bacteria. Biotech Publications, Geneva, N.Y.

5. Marmur, J., and P. Doty. 1962. Determination of the base composition of deoxyribonucleic acid from its thermal denaturation temperature. J. Mol. Biol. 5:109-118. 